\title{
Communicative Tasks and the Language Curriculum
}

\section{David Nunan}

Over the last 25 years the communicative task has emerged as a significant building block in the development of language curricula and also as an element for motivating process-oriented second language acquisition research. This paper reviews the influence of the communicative task on curriculum development and summarizes the research base for task-based language teaching. In the final part of the paper, an agenda for future research is set out.

Over the last 25 years, the communicative task has evolved as an important component within curriculum planning, implementation, and evaluation. In task-based language teaching, syllabus content and instructional processes are selected with reference to the communicative tasks which learners will (either actually or potentially) need to engage in outside the classroom and also with reference to theoretical and empirical insights into those social and psycholinguistic processes which facilitate language acquisition. This approach to language teaching is characterized by the following features;

1. An emphasis on learning to communicate through interaction in the target language

2. The introduction of authentic texts into the learning situation

3. The provision of opportunities for learners to focus, not only on language, but also on the learning process itself

4. An enhancement of the learner's own personal experiences as important contributing elements to classroom learning

5. An attempt to link classroom language learning with language activation outside the classroom

Task-based language teaching has been an important addition to the conceptual and empirical repertoire of the second and foreign language teacher in the eighties, having influenced syllabus design, materials development, and language teaching methodology In this paper, I shall review the development of task-based language teaching (TBLT) In the first part of the paper, I shall provide an account of the theoretical and empirical basis for TBLT. I shall then discuss the influence of TBLT on curriculum development and classroom practice. In the final part of the paper, I indicate the ways in which I believe that the research agenda should be extended in the nineties

\section{THE CONCEPTUAL BASIS}

Like many other innovations, task-based teaching entered the language field from the educational mainstream. Studies of teachers at work demonstrated that, while teacher education programs taught trainees to plan, implement, and evaluate their programs according to the "rational" model which begins with objectives and moves through tasks to evaluation (Tyler, 1949), the reality was that once they began practicing, teachers tended to focus on pedagogic tasks (Shavelson \& Stem, 1981). This insight from research into teachers professional planning and decision-making processes enhanced the status of task as a curriculum planning tool. 
Task-based learning is also linked to mainstream education by its close relationship with experiential learning. This relationship is evident in the following description of experiential learning:

In experiential learning, immediate personal experience is seen as the focal point for learning, giving "life, texture, and subjective personal meaning to abstract concepts and at the same time providing a concrete, publicly shared reference point for testing the implications and validity of ideas created during the learning process," as pointed out by David KoIb (1984: 21). But experience also needs to be processed consciously by reflecting on it. Learning is thus seen as a cyclical process integrating immediate experience, reflection, abstract conceptualization and action. (Kohonen, in press)

To date, definitions of tasks have been rather programmatic. Long (1985a) suggests that a task is nothing more or less than the things people do in everyday life. He cites as examples buying shoes, making reservations, finding destinations, and writing cheques. The Longman Dictionary of Applied Linguistics provides a more pedagogically oriented characterization. Here, it is suggested that a task is

any activity or action which is carried out as the result of processing or understanding language (i.e., as a response). For example, drawing a map while listening to a tape, listening to an instruction and performing a command, may be referred to as tasks. (Richards, Platt, \& Weber, 1985, p. 289)

The value of tasks, according to the authors, is that they provide a purpose for the activity which goes beyond the practice of language for its own sake.

A similar characterization is offered by Breen (1987) who suggests that a task is

any structured language learning endeavour which has a particular objective, appropriate content, a specified working procedure, and a range of outcomes for those who undertake the task. 'Task' is therefore assumed to refer to a range of workplans which have the overall purpose of facilitating language learning - from the simple and brief exercise type, to more complex and lengthy activities such as group problem- solving or simulations and decision making. (p. 23)

Elsewhere, I have suggested that tasks can be conceptualized in terms of the curricular goals they are intended to serve, the input data which forms the point of departure for the task, and the activities or procedures which the learners undertake in the completion of the task. Two important additional elements are the roles for teachers and learners implicit in the task, and the settings and conditions under which the task takes place (Nunan, 1989). Later in this paper, I shall use these elements of goals, input data, activities/procedures, roles, and settings as rubrics for synthesizing the considerable amount of research activity which provides an empirical basis for task-based language teaching and learning. 


\section{THE CURRICULAR BASIS}

Before the development of communicative approaches to language teaching, tasks and exercises were selected as a second order activity, after the specification of the morphosyntactic, phonological, and lexical elements to be taught. Traditionally, curriculum designers and materials writers took as their point of departure the question, What are the grammatical, phonological, and lexical items to be taught? The specification of these items set the parameters for the selection of classroom activities. In other words, selection of classroom activities was driven by curriculum goals specified in phonological, morphosyntactic, and lexical terms. (See, for example, the analysis of content selection and sequencing in a grammar- based syllabus provided by McDonough, 1981, p.21.)

In a task-based curriculum, the decision-making process is quite different. There are, in fact, two different routes which the curriculum developer/materials writer can take in initiating the design process. The first of these is based on what I have called the rehearsal rationale. Here the question initiating the design process is, What is it that learners potentially or actually need to do with the target language? The second is what I have called the psycholinguistic rationale. Here the initiating question is, What are the psycholinguistic mechanisms underlying second language acquisition, and how can these be activated in the classroom? The linguistic elements to be focused on in the classroom are selected as a second order activity.

Ideally, task selection should occur with reference both to target task rationale and psycholinguistic principles. The way that this might be achieved is illustrated in the procedure set out in Figure 1, adapted from a recently published task-based coursebook (Nunan \& Lockwood, 1991). The pedagogic task is selected with reference to the realworld or target task of "giving information in a job interview." Learners are given a model of the target language behaviour, as well as specific practice in manipulating key language items. The actual pedagogic task, a simulation, is also consistent with research on the facilitative effects of classroom interaction (research on language acquisition is reviewed in the next section). 
FIGURE 1

Steps Involved in the Development of a Pedagogic Task

\begin{tabular}{|l|l|l|}
\hline Procedure & Example & Rationale \\
\hline 1. Identify target task & $\begin{array}{l}\text { Giving personal information } \\
\text { in a job interview }\end{array}$ & $\begin{array}{l}\text { To give learners the } \\
\text { opportunity to develop } \\
\text { language skills relevant to } \\
\text { their real world needs }\end{array}$ \\
\hline 2. Provide model & $\begin{array}{l}\text { Students listen to and } \\
\text { extract key information } \\
\text { from authentic/simulated } \\
\text { interview }\end{array}$ & $\begin{array}{l}\text { To provide learners the } \\
\text { opportunity to listen to and } \\
\text { analyse ways in which } \\
\text { native speakers or users of } \\
\text { the target language carry } \\
\text { out the target task }\end{array}$ \\
\hline 3. Identify enabling skill & $\begin{array}{l}\text { Manipulation drill to } \\
\text { practice wh-questions with } \\
\text { do-insertion }\end{array}$ & $\begin{array}{l}\text { To provide learners with } \\
\text { explicit instruction and } \\
\text { guided practice in those } \\
\text { grammatical elements } \\
\text { needed to perform the target } \\
\text { task }\end{array}$ \\
\hline 4. Devise pedagogic task & $\begin{array}{l}\text { Interview simulation using } \\
\text { role cards }\end{array}$ & $\begin{array}{l}\text { To provide learners the } \\
\text { opportunity to mobilize } \\
\text { their emerging language } \\
\text { skills through rehearsal }\end{array}$ \\
\hline
\end{tabular}

The growing importance of the pedagogic task as a central element within the curriculum has called into question the conventional distinction between syllabus design and methodology. Traditionally, syllabus design is concerned with the selection and grading of content, while methodology is concerned with the selection and sequencing of tasks, exercises, and related classroom activities. Metaphorically speaking, syllabus design is concerned with the destination, while methodology is concerned with the route. With the development of task-based approaches to language learning and teaching, this distinction has become difficult to sustain. Breen (1984) has neatly captured this change of focus in the following way:

[TBLT would] prioritize the route itself; a focusing upon the means towards the learning of a new language. Here the designer would give priority to the changing process of learning and the potential of the classroom - to the psychological and social resources applied to a new language by learners in the classroom context. . . . a greater concern with capacity for communication rather than repertoire of communication, with the activity of learning a language viewed as important as the language itself, and with a 
focus upon means rather than predetermined objectives, all indicate priority of process over content. (pp. 52-53)

Conceptually, then, task-based language teaching has been influenced by developments in mainstream education as well as by major conceptual shifts in our understanding of the nature of language and language learning. It has also been enhanced by a research agenda which has provided an empirical basis upon which curriculum designers, materials writers, and classroom practitioners can draw. The availability of empirical data on tasks has enhanced the status of task-based language teaching at a time when the various "methods" approaches to language teaching have come under increasing criticism for lacking an empirical basis. (See, for example, Long, 1990; Richards, 1990). In the next section, I shall provide a selective review of this research.

\section{THE EMPIRICAL BASIS}

One of the strengths of task-based language teaching is that the conceptual basis is supported by a strong empirical tradition. This distinguishes it from most methods approaches to pedagogy, which are relatively data-free. I have already suggested that tasks can be conceptualized in terms of the key elements of goals, input data, activities/procedures, roles, and settings. This conceptual scheme provides a convenient means of synthesising the research on tasks.

Task goals enable the program planner and materials writer to provide explicit links between the task and the broader curriculum it is designed to serve. Without clearly articulated sets of goal statements, there is a risk that task-based teaching programs will lack coherence as Widdowson (1987), among others, has pointed out. Goals are generally referenced against the sorts of things which learners want to do with the language outside the classroom. Typical goal statements include:

1. To develop the skills necessary to take part in academic study

2. To obtain sufficient oral and written skills to obtain a promotion from unskilled worker to site supervisor

3. To communicate socially in the target language

4. To develop the survival skills necessary to obtain goods and services

5. To be able to read the literature of the target culture

Despite its importance for coherent curriculum development, compared to other areas, research on task goals is difficult to find in the literature. One of the few available studies is that by Brindley (1984) who investigated the needs analysis, goal and objective setting practices of teachers of ESL to adults, and the reaction of learners to these practices. Based on an extensive series of interviews, Brindley found that programs in which the goals were explicit and reflected the communicative needs of the learners had greater face validity than those in which the goals were either unstated, inexplicit, or which did not reflect learners' goals. While there was no direct evidence that programs with explicit, relevant goals resulted in more effective learning outcomes, it is not unreasonable to expect that this would be the case, given what we know about the relationship between affective/attitudinal factors and learning outcomes. 
Most tasks take as their point of departure input data of some sort. Such data may be linguistic (that is, reading and listening texts of various sorts) or nonlinguistic (for example, diagrams, photographs, picture sequences). This area is considerably better researched than that of goals. A key question underlying research on input tasks is, What factors are implicated in the difficulty of aural and written texts?

In a large-scale investigation of the listening comprehension of secondary students, Brown and Yule (1983) found that two factors significantly affected the difficulty of listening texts. The first factor related to the number of elements in the text and the ease and difficulty of distinguishing between them. The second significant factor was the text type. All other things being equal, descriptions were easier than instructions, which were easier than stories. Arguments or opinion-expressing texts containing abstract concepts and relationships were the most difficult. Follow-up research cited in Anderson and Lynch (1988) identified a number of other factors $w$ including the following: :

1. The way the information is organized (narrative texts in which the order of events in the texts mirrors the order in which the events actually occurred in real life are easier to comprehend than narratives in which the events are presented out of sequence)

2. The familiarity of the topic

3. The explicitness and sufficiency of the information

4. The type of referring expressions (for young children, pronominal referents are more difficult to comprehend than full noun phrase referents)

5. Text type

In the area of reading comprehension, Nunan (1984) found that similar elements were implicated in the difficulty of school texts for secondary level students. Nunan looked, among other things, at the difficulty of different types of textual relationships as well as at the effect of content familiarity. He found that logical relationships of the type marked by conjunctions were more difficult than referential and lexical relationships. He also found that content familiarity was more significant than grammatical complexity in determining the difficulty of reading texts.

The bulk of task-based research has focused on the activities or procedures which learners carry out in relation to the input data. The key question here has been, What tasks seem to be most helpful in facilitating second language acquisition?

In the first of a series of investigations into learner-learner interaction, Long (1981) found that two-way tasks (in which all students in a group discussion had unique information to contribute) stimulated significantly more modified interactions than one-way tasks (that is, in which one member of the group possessed all the relevant information). Similarly, Doughty and Pica (1986) found that required information-exchange tasks generated significantly more modified interaction than tasks in which the exchange of information was optional. (Modified interactions are those instances in which speakers modify their language in order to assure that they have been correctly understood; they result from an indication of noncomprehension usually on the part of a listener) 
These investigations of modified interaction were theoretically motivated by Krashen's (1981, 1982) hypothesis that comprehensible input was a necessary and sufficient condition for second language acquisition - in other words, that acquisition would occur hen learners understood messages in the target language. Long (1985b) advanced the following argument in favor of tasks which promote conversational adjustments or interactional modifications on the part of the learners taking part in the task:

Step 1: Show that (a) linguistic/conversational adjustments promote (b) comprehensible input.

Step 2: Show that (b) comprehensible input promotes (c) acquisition.

Step 3: Deduce that (a) linguistic/conversational adjustments promote (c) acquisition.

Satisfactory evidence of the a-b-c relationships would allow the linguistic environment to be posited as an indirect causal variable in SLA. (The relationship would be indirect because of the intervening "comprehension" variable.) (p. 378)

In the fast few years the comprehensible input hypothesis has been criticised on theoretical and empirical grounds. For example, Swain (1985) demonstrated that immersion programs in Canada, in which learners received huge amounts of comprehensible input did not lead to the sort of native-like facility in the target language predicted by the input hypothesis. She proposed that in addition to comprehensible input, learners need opportunities that require that :heir own speech be comprehensible because it is only through such opportunities that learners are pushed to mobilize their emerging grammatical competence. (Such mobilization is precisely what the tasks suggested by Long, 1985b; Doughty \& Pica, 1986; and others manage to achieve. In other words, their research may be justified on grounds other than that proposed by the comprehensible input hypothesis.)

More recently, attention has focused on the question of the types of language and discourse patterns stimulated by different task types. Berwick (1988, in press) investigated the different types of language stimulated by transactional and interpersonal tasks. (A transaction task is one in which communication occurs principally to bring about the exchange of goods and services, whereas an interpersonal task is one in which communication occurs largely for social purposes.) He found that the different functional purposes stimulated different morphosyntactic realizations.

In a recent study, I investigated the different interactional patterns stimulated by open and closed tasks. (An open task is one in which there is no single correct answer, while a closed task is one in which there is a single correct answer or a restricted number of correct answers.) It was found that the different task types stimulated very different interactional patterns. This can be seen in the following extracts. In Task A, the relatively closed task, the students are required to sort 20 vocabulary cards into semantic fields. In Task B, having read a text on the topic of habits, the students are required to have an open-ended discussion on the topic of bad habits. (Both extracts are adapted from Nunan, 1991.) 
Extract from Task A

Two students, Hilda and Carlos, are studying the following words which have been typed onto pieces of cardboard. Their task is to group the words together in a way which makes sense to them. There is silence for several minutes as the students study the cards:

GEOGRAPHY, ASTRONOMY, AGRICULTURE, ECONOMICS, COMMERCE, ENGLISH, SCIENCE, STATISTICS, BOOK, COMPUTER, PENCIL, DIARY, NEWSPAPER, MAGAZINE, THAILAND, HONG KONG, MELBOURNE, DARWIN, UNITED STATES, ASIAN, DIAGRAM, ILLUSTRATION, PICTURE, CARTOON, VIDEO, COMPETENT, LAZY, INTERESTING, SUPERIOR, UNCOMFORTABLE, REGION.

H: Statistic and diagram — they go together. You know diagram?

C: Yeah.

H: Diagram and statistic are family. . . but maybe, I think, statistic and diagram-you

think we can put in science? Or maybe. .

$\mathrm{C}$ : Science, astronomy, [yeah) and er can be agriculture.

$\mathrm{H}$ : Agriculture's not a science.

C: Yes, it's similar

H: No.... er may be Darwin and science....

C: What's the Darwin?

$\mathrm{H}$ : Darwin is a man.

C: No, it's one of place in Australia.

H: Yes, but it's a man who discover something, yes, I'm sure.

$\mathrm{C}: \mathrm{OK}$.

H: And maybe, look, yes, picture, newspaper, magazine, cartoon, book, illustration

C: [yeah). Maybe we can put lazy and English together. Er Hong Kong, Thailand

together. Asian. Er, United States. Diary with picture, newspaper and so on. . . O Oh, I

understand, look, look. Here, it's only adjective-lazy, competent, interesting and

comfortable. Er, what is it? Ah yes yes. (She begins to tearrange the cards.)

C: Darwin

Extract from Task B

Maria, Martha, Sylvia, and Sandy are taking part in a small-group discussion on the topic of bad habits.

Maria: My next door neighbour ... he make eh very noisy, very noisy [yeah]. I can't tell him because he's very good people.

(The discussion continues for several minutes.)

Sylvia: . . . you don't want to say anything because you might get upset, of course. Me do the same thing because I've got neighbours in my place and always you know do something I don't like it but I don't like to say had because I think maybe, you, know make him upset or.... 
Martha: I've got bad neighbour but I feel embarrass....

Sylvia: . . . to say something of course, like everyone....

Martha: They always come in and see what I'm doing-who's coming. [no good) [yeah, that's no good) They want to check everything. If they see I buy something from the market they expect me to give them some. [oh yeah). [oh that's not nice] But I ... it's difficult.

Sylvia: It's a difficult, yeah, but sometime it's difficult ....

Martha: They can't understand, I bought them and I gave money (laughter) [yeah]

Martha: You know sometime difficult to the people because sometime I can't speak the

proper, the language, and little bit hard to give to understand . . . and that's - sometime

feel embarrass then, I can't say it, you know?

Maria: [turns to the fifth woman, who has not yet spoken) Sarah, you tell [you tell now]

Sarah: My, er, for example, my sister in law she all the time snores in her sleep [oh, yes)

And my brother say, "Oh, I'm sorry, we must sleep separate” [separate beds] (laughter).

They did. [good idea) A good idea because he couldn't sleep. (Laughter.)

In addition to the fact that the different task types stimulated different interactional patterns, the research also indicated that some task types might be more appropriate than others for learners at particular levels of proficiency. In the above study, it was found that with lower-intermediate to intermediate learners, the relatively closed tasks stimulate more modified interaction than relatively more open tasks. This is not to say that such students should engage in closed tasks to the exclusion of open tasks. The important thing is that program planners and teachers should select a mix of tasks to reflect the pedagogic goals of the curriculum.

Another element considered within task design is that of teacher/learner roles. All pedagogic tasks contain roles for teachers and learners, and conflict is likely to occur if there is a misapprehension between teachers and learners about their respective roles. Research related to learner roles has come up with findings which run counter to the folk wisdom of the classroom. For instance, Bruton and Samuda (1980) found that learners are capable of correcting each other successfully. Additionally, according to Porter (1986), learners produce more talk with other learners than with native-speaking partners, and learners do not learn each other's errors. Finally, Gass and Varonis (1985) found that there were advantages, when conducting groupwork, to pairing learners of different proficiency levels as well as from different language backgrounds.

The final element is that of setting, which refers to the learner configuration (either teacher-fronted, small group, pair, or individual), as well as the environment (whether the task takes place in the classroom or outside the classroom). One of the first task studies to be carried out, that by Long, Adams, and Castanos (1976), found that small-group tasks prompt students to use a greater range of language functions than teacher-fronted tasks. In relation to environment, Montgomery and Eisenstein (1985) found that supplementing classroom tasks with community-based experiences resulted in significantly increased language gains. 


\section{FUTURE DIRECTIONS: EXTENDING THE RESEARCH AGENDA}

Most of the research carried out during the eighties and described in the preceding section was driven by Krashen's input hypothesis, which is based on the belief that opportunities for second language acquisition are maximised when learners are exposed to language which is just a little beyond their current level of competence (Krashen, 1981, 1982). The central research issue here is, What classroom tasks and patterns of interaction provide learners with the greatest amount of comprehensible input? It has been argued that patterns of interaction in which learners are forced to make conversational adjustments promote acquisition. As I have already pointed out, this view represents an indirect rather than direct relationship between environmental factors (for example, types of instruction) and language acquisition. I also referred to research which, while questioning the comprehensible input hypothesis, supported the communicative tasks to which it gave rise.

While the research reviewed in the preceding section represents a healthy state of affairs, the scope needs to be developed and extended both substantively and methodologically. In substantive terms, the research agenda needs to incorporate a greater range of linguistic and psycholinguistic models. Methodologically, the scope of the research needs to be extended by the utilization of a greater range of research tools and techniques. In particular, it would be useful to see the emergence of research which explored the relationships between contextual factors, interpersonal factors, learner proficiency levels; and pedagogic tasks.

In order to indicate the ways in which these principles might influence the shape of future research, I shall briefly review two recent investigations which provide useful indications of the ways in which research on task-based language teaching and learning can be extended both substantively and methodologically.

Berwick (1988; in press) exemplifies the advantages of extending the research agenda on tasks by drawing on insights from a range of theoretical models. Of particular interest is his utilization of functional grammars, specifically the systemic-functional model first articulated by Halliday (see, for example, Halliday, 1985; Halliday \& Hasan, 1976; Halliday \& Hasan, 1989). This particular model of language attempts to draw explicit links between the functions which language exists to fulfil and its realization at the level of lexicogrammatical choice. In his research, Berwick (1988) explored differences at the level of lexicogrammar attributable to different task types. In classifying tasks, he distinguished between pedagogical and collaborative goals on one hand, and expository and experiential processes on the other. Tasks with pedagogical goals are concerned with the transfer of information through explicit instruction, while collaborative tasks "emphasized cooperative, consensual behaviour and exchange of information about a problem or topic which participants explore freely during the task itself" (Berwick, in press). Tasks based on expository processes are concerned with theoretically based knowledge, whereas experiential processes are concerned with procedural knowledge (in familiar terms, the former is concerned with theoretical knowing [knowing that], while the latter is concerned with practical knowledge [knowing how]). Berwick uses these two 
dimensions to situate a range of tasks which he used in his study. These are set out in Figure 2. A description of the tasks follows.

Task COM1: This task, residing at the expository end of the process continuum and the pedagogical end of the goal continuum, consisted of a lecture about finding string characters in a text through use of the word-processing program of a personal computer, not physically present in the experimental setting.

Task COM2: This task shared the pedagogical goal of COM1, but was more experiential in that it involved a demonstration of how to find character strings on the laptop computer when it was physically present in front of the participants.

Task LEC1: Participants in this task faced away from each other. One participant had a small Lego toy made of snap-together plastic parts which had to be described so that the second participant was able to assemble a replica of the toy.

Task LEC2: This task was similar to LEG1, except that participants sat face-to-face.

Task DIS: The Final task was an informal discussion of any topic of common interest to the participants.

The independent variable in Berwick's study was the task. Dependent variables included a range of discourse features associated with the negotiation of meaning in interaction and utilized in many of the task investigations based on the input hypothesis. Variables included clarification requests, comprehension checks, confirmation checks, definitions, display questions, echoes, expressions of lexical uncertainty, referential questions, selfexpansions, self-repetitions, and other-repetitions.

\section{FIGURE 2}

Goal and Process Dimensions of the Five Tasks Used in the Berwick Study From "Towards an Educational Framework for Teacher-led Tasks in English as a Foreign Language" by R.Berwick, in press, in Task-Based Language Teaching edited by G. Crookes \& S. Gass. Copyright Multilingual Matters. Reprinted by permission.

\begin{tabular}{|l|l|l|l|}
\hline & & Processes & \\
\hline Goals & Expository & & Experiential \\
\hline Pedagogical & COM1 & & COM2 \\
\hline Collaborative/Social & LEG 1 & DIS & LEG2 \\
\hline
\end{tabular}

Berwick (in press) established through his research that task type is an important determinant of lexicogrammatical exponents. He was also able to relate the tasks and exponents to an educational framework which provides a broad pedagogical rationale for task- based language teaching. I have described his research at some length because it exemplifies the value of drawing on a range of theoretical models in the development of research programs into task-based language teaching and learning.

The second study reviewed in this section is by Duff (in press). Duff carried out a longitudinal case study of a single learner, investigating the extent to which performance on different types of tasks yielded different types of information on the subject's 
interlanguage. The three tasks investigated included an interview conversation, a picture description, and a Cambodian folktale narration. The dependent measures included the amount of language produced, the range of vocabulary elicited, nominal reference, and negation. Data were collected from a 24-year-old Cambodian male, over a 2-year period.

Duff's study yielded mixed results. While there was some evidence of task-related variability, the subject's performance from one data-collection period to the next also exhibited variability. The study raised five fundamental questions: (a) Are the tasks selected distinct enough to be operationalizable constructs in this type of analysis? (b) Assuming the constructs are valid, are there any meaningful differences across tasks? (c) To what extent can variability be ascribed to other constructs such as genre or topic? (d) Were the features investigated by the researcher the salient ones, or should this line of research be restricted to those features of interlanguage morphology and phonology which have been found to be salient? (e) How is the researcher to account for those differences which were observed?

Duff's study is significant within the current context because it represents a departure from the cross-sectional research which has typified the field since its inception. While the longitudinal case study has been usefully employed in other aspects of SLA research (see, for example, Schmidt, 1983) it is uncommon in research on tasks. In the five fundamental questions she raises as a result of her study, Duff also provides a basis for a substantial research agenda for further research. Finally, she places the issue of interlanguage tt variability firmly on the research agenda. Looking to the future, I would like to see the issue of variability feature more prominently in research into task-based language learning and teaching.

\section{CONCLUSION}

In this paper I have provided a selective overview of the development of task-based language teaching. I have tried to show that, while it had its genesis in mainstream education, task-based teaching has become a powerful influence in language education. At a conceptual level, the approach has been supported by changing conceptions of the nature of language and learning - captured under the rubric of communicative language teaching. Empirically, TBLT is supported by a healthy research agenda which emerged from process-oriented second language acquisition.

In the second part of the paper, I have tried to indicate some of the directions that TBLT might take in the future. In particular, I have suggested that the conceptual and empirical basis needs to be extended both substantively and methodologically, and I described two recent investigations which illustrate the possible shape of research under such an extended agenda. 


\section{REFERENCES}

Anderson, A., \& Lynch, T. (1988). Listening. Oxford: Oxford University Press.

Berwick, R. (1988). The effect of task variation in teacher-led groups on repair of English as a foreign language. Unpublished doctoral dissertation, University of British Columbia, Vancouver, Canada.

Berwick, R. (in press). Towards an educational framework for teacher-led tasks in English as a foreign language. In C. Crookes \& S. Gass (Eds.), Task-based language teaching. Clevedon, Avon, England: Multilingual Matters.

Breen, M. (1984). Process syllabuses for the language classroom. In C. Brumfit (Ed.), General English syllabus design. Oxford: Pergamon Press.

Breen, M. (1987). Learner contributions to task design. In C. Candlin \& D. Murphy (Eds.), Language learning tasks. Englewood Cliffs, NJ: Prentice Hall.

Brindley, G. (1984). Needs analysis and objective setting in the Adult Migrant Education Service. Sydney: Adult Migrant Immigration Service.

Brown, C., \& Yule, C. (1983). Teaching the spoken language. Cambridge: Cambridge University Press.

Bruton, C., \& Samuda, C. (1980). Learner and teacher roles in the treatment of oral error in group work. PLELC Journal, 11(3), 49-63.

Doughty, C., \& Pica, T. (1986). "Information gap" tasks: Do they facilitate second language acquisition? TESOL Quarterly, 20(3), 305-325.

Duff, P. (in press). Task force on interlanguage performance: An analysis of task as independent variable. In C. Crookes \& S. Cass (Eds.), Task- based language teaching. Clevedon, Avon, England: Multilingual Matters.

Gass, S., \& Varonis, E. (1985). Task variation and nonnative/nonnative negotiation of meaning. In S. Cass and C. Madden (Eds.), Input in second language acquisition. Rowley, MA: Newbury House.

Halliday, M. A. K. (1985). An introduction to functional grammar. London: Edward Arnold.

Halliday, M. A. K., \& Hasan, R. (1976). Cohesion in English. London: Longman. Halliday, M. A. K., \& Hasan, R. (1989). Language, context and text: Aspects of language in a social semiotic perspective. Oxford: Oxford University Press.

Kohonen, V. (in press). Experiential language learning: Second language learning as cooperative learner education. In D. Nunan (Ed.), Collaborative language learning and teaching. Cambridge: Cambridge University Press.

KoIb, D. (1984). Experiential learning: Experience as the source of learning and development. Englewood Cliffs, NJ: Prentice Hall.

Krashen, S. (1981). Second language acquisition and second language learning. Oxford: Pergamon Press.

Krashen, S. (1982). Principles and practice in second language acquisition. Oxford: Pergamon Press.

Larsen-Freeman, D., \& Long, M. H. (in press). An introduction to second language acquisition research. London: Longman.

Long, M. H. (1981). Input, interaction and second language acquisition. In H. Winitz (Ed.), Native language and foreign language acquisition (Annals of the New York Academy of Sciences No. 379, pp. 259-278). New York: New York Academy of 
Sciences.

Long, M. H. (1985a). A role for instruction in second language acquisition: Task-based language training. In K. Hyltenstam \& M. Pienemann (Eds.), F Modelling and assessing second language acquisition Clevedon Avon England: Multilingual Matters.

Long, M. H. (1985b). Input and second language acquisition theory. In S. Cass \& C. Madden (Eds.), Input in second language acquisition. Rowley, MA: Newbury House. Long, M. II. (1990). Task, groups, and task-group interactions. In S. Anivan (Ed.), Language teaching methodology for the nineties. Singapore: RELC.

Long, M. H., Adams, L., \& Castanos, F. (1976). Doing things with words: Verbal interaction in Iockstep and small group classroom situations. In B. Crymes \& J. Fanselow (Eds.), On TESOL '76. Washington, DC: TESOL.

McDonough, S. (1981). Psychology in foreign language teaching. London: Alien \& Unwin.

Montgomery, C., \& Eisenstein, M. (1985). Heal reality revisited: An experimental communicative course in ESL. TESOL Quarterly, 19(2), 317-334.

Nunan, D. (1984). Discourse processing by first language, second phase, and second language learners. Unpublished doctoral dissertation, Flinders University of South Australia, Adelaide.

Nunan, D. (1989). Designing tasks for the communicative classroom. Cambridge: Cambridge University Press.

Nunan, D. (1991). Language teaching methodology: A textbook for teachers. London: Prentice Hall.

Nunan, D., \& Lockwood, J. (1991). The Australian English course: Task- based English for post-beginners. Cambridge: Cambridge University Press.

Porter, P. (1986). How learners talk to each other: Input and interaction in task-centered discussions. In B. Day (Ed.), Talking to learn: Conversation in second language acquisition. Rowley, MA: Newbury House.

Richards, J. C. (1990). The language teaching matrix. Cambridge: Cambridge University Press.

Richards, J. C., Platt, J., \& Weber, H. (1985). Longman dictionary of applied linguistics. London: Longman.

Schmidt, B. (1983). Interaction, acculturation, and the acquisition of communicative competence: A case study of an adult. In N. Wolison \& E. Judd (Eds.), Sociolinguistics and language acquisition. Rowley, MA: Newbury House.

Shavelson, R. J., \& Stern, P. (1981). Research on teachers' pedagogical thoughts, judgments and behaviour, Review of Educational Research, 51,4.

Swain, M. (1985). Communicative competence: Some roles of comprehensible input and comprehensible output in its development. In S. Cass \& C. Madden (Eds.), Input in second language acquisition. Rowley, MA: Newbury House.

Tyler, B. (1949). Basic principles of curriculum and instruction. New York: Harcourt Brace.

Widdowson, H. C. (1987). Aspects of syllabus design. In M. Tickoo (Ed.), Language syllabuses: State of the art. Singapore: RELC. 